Check for updates

Montreal

Cite this as: $B M J$ \$ $\{$ year\};374:n2228 http://dx.doi.org/10.1136/bmj.n2228 Published:

\title{
Covid-19: Hospital may cease giving patient ivermectin, US court rules, as prescriptions soar
}

\section{Owen Dyer}

An Ohio judge has overturned an earlier court order that forced a hospital to treat a covid-19 patient with the antiparasitic drug ivermectin, popularised by US conservative media.

West Chester Hospital was ordered to administer the unproved drug by a county judge on 23 August, after Julie Smith sued on behalf of her husband, Jeffrey Smith, who has been in intensive care since 15 July and on a ventilator since 1 August.

Julie Smith launched her lawsuit after the hospital declined to fill a prescription she had obtained from Fred Wagshul, one of three doctors who last year founded the Front Line COVID-19 Critical Care Alliance (FLCCCA), a group that has spread claims of ivermectin's efficacy against the coronavirus.

The hospital followed the court order to give the drug but appealed, and this week Butler County common pleas judge Michael Oster overturned the previous ruling that had ordered that Smith receive a three week course of treatment. ${ }^{1}$ Two weeks' have already been given.

The appeal heard that Wagshul, who lacks board certification and has not worked in a hospital for 10 years, would not qualify for practising privileges at the hospital where Smith is being treated.

Julie Smith's lawyer Ralph Lorigo, who is chairman of Erie County's Conservative Party, has already successfully sued to force two hospitals in New York and one in Chicago to administer ivermectin. ${ }^{23}$

The hospital told the court that Smith remains sedated on a ventilator, his condition unchanged. But Lorigo told reporters after the trial that he had won a moral victory because Smith had received the drug for two weeks. "My client has won this case. I don't care what this judge says. We are believers he's going to survive because of ivermectin."

Neither Julie Smith nor her husband have been vaccinated against SARS-CoV-2, she told the court, saying that the vaccine was "experimental" and she didn't trust it. "We didn't feel confident it had been out long enough,” she testified.

Wagshul said that the government and drug industry had "censored" information about ivermectin's benefits.

Those warning against taking ivermectin for covid-19 include the drug's own maker, Merck, which said that its analysis had found "no scientific basis for a potential therapeutic effect against covid-19 from pre-clinical studies; no meaningful evidence for clinical activity or clinical efficacy in patients with covid-19 disease; and a concerning lack of safety data in the majority of studies." 4
Also warning against the drug's use to treat covid-19 were the Food and Drug Administration, ${ }^{5}$ American Medical Association, ${ }^{6}$ American Pharmacists Association, and the World Health Organization. ${ }^{7}$

Despite these warnings, support for ivermectin from three Fox News hosts, Tucker Carlson, Sean Hannity, and Laura Ingraham, has coincided with a sharp recent spike in prescriptions. Data from mid-August showed 88 ooo prescriptions a week, the US Centers for Disease Control and Prevention said, 24 times higher than usual. This coincided with a fivefold increase in calls to US poison control centres. ${ }^{8}$

On 8 September New Mexico's acting secretary of health, David Scrase, reported in his pandemic update that his state had seen the first known death from covid related ivermectin poisoning. Another patient was in intensive care, he said. ${ }^{9}$

Ivermectin sales have also surged in Australia, where a 2020 in vitro study first claimed efficacy for the drug against covid-19. ${ }^{10}$ The Therapeutic Goods Administration reported a shortage in August, and the Pharmaceutical Society of Australia said this month that pharmacists had seen an increase in prescriptions, often presented by people who refused to discuss their reason for wanting it. ${ }^{11}$

Julie Smith v West Chester Hospital. Case Number: CV 202108 1206. 6 September 2021. https://www.documentcloud.org/documents/21055887oster-order.

2 Herbeck D, Williams D. 2nd WNY hospital ordered to treat covid-19 patient with experimental drug. Buffalo News. Feb 2021. https://buffalonews.com/news/local/2nd-wny-hospital-ordered-to-treat-covid-19 patient-with-experimental-drug/article_f32339f0-5d01-11eb-b7524f8966804581.html.

3 Keilman J. After court order, Elmhurst Hospital says it's allowing covid-19 patient to receive controversial drug ivermectin. Chicago Tribune. 4 May 2021. https://www.chicagotribune.com/coronavirus/ct-elmhurst-hospitalivermectin-covid-court-order-20210504-2dvay7tatzartk2ijv23hgdxw4story.html.

4 Merck statement on ivermectin use during the covid-19 pandemic. Feb 2021. https://www.merck.com/news/merck-statement-on-ivermectin-useduring-the-covid-19-pandemic.

FDA. Why you should not use ivermectin to treat or prevent covid-19. Sep 2021. https://www.fda.gov/consumers/consumer-updates/why-you-shouldnot-use-ivermectin-treat-or-prevent-covid-19.

6 AMA. APhA, ASHP statement on ending use of ivermectin to treat covid-19. Sep 2021. https://www.ama-assn.org/press-center/press-releases/amaapha-ashp-statement-ending-use-ivermectin-treat-covid-19.

WHO advises that ivermectin only be used to treat COVID-19 within clinical trials. World Health Organization. Mar 2021. https://www.who.int/newsroom/feature-stories/detail/who-advises-that-ivermectin-only-be-used-totreat-covid-19-within-clinical-trials.

8 Rapid increase in ivermectin prescriptions and reports of severe illness associated with use of products containing ivermectin to prevent or treat covid-19. CDC Health Alert Network. Aug 2021. https://emergency.cdc.gov/han/2021/han00449.asp.

9 New Mexico state officials provide covid-19 update. Sep 2021 https://www.face-

book.com/watch/live/?v=454210902378513\&ref=watch_permalink.

10 Caly L, Druce JD, Catton MG, Jans DA, Wagstaff KM. The FDA-approved drug ivermectin inhibits the replication of SARS-CoV-2 in vitro. Antiviral Res 2020;178:104787. doi: 10.1016/.j.antiviral.2020.104787. pmid: 32251768 
11 Taylor J. Australian pharmacists report rise in customers refusing to say what ivermectin prescription is for. Guardian. Sep 2021. https://www.theguardian.com/australia-

news/2021/sep/01/australian-pharmacists-report-rise-in-customers-refusing-to-say-what-ivermectin-prescription-is-for.

This article is made freely available for use in accordance with BMJ's website terms and conditions for the duration of the covid-19 pandemic or until otherwise determined by BMJ. You may use, download and print the article for any lawful, non-commercial purpose (including text and data mining) provided that all copyright notices and trade marks are retained. 